\title{
REGIONAL EMPLOYMENT GENERATION POTENTIAL OF THE TURKISH LABOR MARKET: AN INTER-SECTORAL PERSPECTIVE
}

\author{
Umut GÜNDÜZ ${ }^{\mathrm{a}}$, Tolga KAYA ${ }^{\mathrm{b}}$ \\ Management Engineering Department, Faculty of Management, \\ Istanbul Technical University, 34367 Beşiktaş, İstanbul, Turkey
}

Received 24 July 2013; accepted 31 August 2014

\begin{abstract}
Contractionary effects of the current global crisis are not homogenous among sectors. Moreover, sectoral employment multipliers and high regional unemployment differentials unequally transfer these effects into labor market. The purpose of this study is to explore the inter-sectoral sensitivities of regional labor markets in Turkey to changes in the final demand. To do this, we decompose the labor demand by sectors and by regions using input-output methodology. Own employment generation effects and regional employment multipliers of each sector are calculated. Overall findings constitute an employment generation map of Turkey. One of the major findings is the strength of the mutual relationship between agriculture and manufacturing sectors. The biggest spillover effect is created by manufacturing upon mostly agriculture, trade and transportation. Agriculture, social services and trade are the most sensitive sectors to changes in the final demand. At regional level; trade, social services and manufacturing are the most influential sectors on Istanbul. Besides, agriculture, social services and construction sectors have the highest employment generation potentials in South Eastern Anatolia.
\end{abstract}

Keywords: Input-Output models, employment generation, Turkey, regional employment policy decision.

JEL Classification: E24, I38, C67.

\section{Introduction}

Spatial consequences of economic policies may not be homogeneous due to sectoral differentials in the structure of regional labor markets. This is also relevant for Turkey. During the period of 1954-1980, Turkey pursued industrialization policies based on import substitution. Due to the dependence of the Turkish industry on imported capital goods and raw

Corresponding author Umut Gündüz

E-mail: gunduzu@itu.edu.tr 
materials, import substitution practices resulted in chronic trade deficits and a balance of payments crisis. To overcome this crisis, Turkey implemented a structural adjustment and stabilization program in 1980s. In the next two decades, Turkish economy has become more open (Günçavdı et al. 2003). The transition of the economy during 1980s has also changed the overall composition of employment and production and, as a result, the difference in development between the eastern and the western parts of Turkey has become more apparent (Filiztekin 2009).

Turkey's economic geography shows a dualistic structure. Eastern part of the country is significantly less developed. The inequalities in wages, the divide in the education level, the lack of (private/public) investment, the weakness of the industrial sector, and the dependence on the agriculture sector in east were highlighted as the main drivers in the past to justify the East-West polarization (Celebioglu, Dall'erba 2010; Elveren 2010; Gezici, Hewings 2004). The effects of regional disparity can be observed on socio-economic factors such as income distribution, life expectancy, human capital, migration and the informal economy. For the case of Turkey, regional differences are considered among the main factors behind the transformation process of rural-agricultural labor force into urban-industrial workers (Gezici, Hewings 2007; Tunalı 2003; Filiztekin 2009).

In 1990s and 2000s Turkey continued to liberalize its foreign trade and experienced an export boom, particularly of manufacturing products. However, as a result of labor productivity growth and increased capacity utilization, employment generation of major export sectors remained at moderate levels. In an environment of large foreign capital inflows and an overvalued currency, recent global economic recession caused a widespread and persistent unemployment issue. Due to likely contractions in export demand, it is predicted that the crisis will have additional negative effects on growth and employment structure in Turkey (Günlük-Şenesen, Şenesen 2011; Onaran 2009; Rodrik 2012).

The need for an analytical framework which can provide insight on sectoral production and employment patterns focusing on regional differences is not restricted to developing economies. In the literature, there are many studies that investigate regional disparities in the employment structures of developed countries. Constantini and Lupi (2006) explored the regional unemployment rates and the disparities between the Northern and the Southern regions of Italy. Li et al. (2011) inspected the relationship between new business formations and employment generation with county level data for the US economy. Koster (2011) compared the regional employment effects of individual foundings with organizational foundings in Netherlands. Niebuhr et al. (2012) analyzed the effects of labor mobility on regional wage convergence in Germany. Karahasan and Lopez-Baso (2013) investigated the relationship between regional differences in the industrial mix, market access, and the spatial dependence in the distribution of human capital in Spain. Incorporating the gender dimension into the analysis, Abe (2013) underlined the great regional variation of labor market characteristics for women in Japan.

Furthermore, in their study on 8 industrial and 17 developing countries (including BRICS), Shankar and Shah (2003) reported that the level of regional inequality is significantly higher in developing countries. The authors argue that there are two plausible reasons for this difference: inter-regional barriers and policies in favor of growth. Inter-regional barriers may 
arise in the forms of institutional, infrastructural and cultural barriers. On the other hand, a greater focus on growth may force developing countries to concentrate their developmental efforts on fewer regions. Other regional studies pointed equally important issues concerning the developing world: Kanbur and Zhang (1999) assessed the relationship between restrictions on inter-regional migration and regional disparity within China. In his study on Brazil, Jonasson (2011) explored why the degree of informal employment may vary substantially between different regions within a country. Likewise, Baltagi et al. (2013) investigated the relationship between wage levels and regional unemployment in Turkey and estimated wage curves for informal and formal workers. Despite being conducted from a regional point of view, these studies lacked the inter-sectoral perspective of Input-Output (I-O) models which consider the interdependencies between different branches of an economy when investigating employment.

I-O analysis was developed by Wassily Leontief (1936), who received the Nobel Prize in 1973 for this contribution. The methodology provides a theoretical framework which can successfully evaluate the relationship between employment and final demand (Miller, Blair 2009). According to the I-O modeling perspective, different sectors support a different level of total employment for a given level of spending on each sector's products. Therefore, different expenditure structures by producers, consumers, government and foreign customers imply variations in the level of total employment (Laitner et al. 1998). There is a vast I-O modeling literature devoted to the impacts of sector specific policies on the employment structure. LeSage and Magura (1991) showed that inter-industry I-O table linkages provide useful information that can be effectively incorporated into labor market forecasting models. Edler and Ribakova (1994) analyzed the impact of industrial robots on the level and structure of employment in Germany. More recently, Sauian et al. (2013) studied the labor productivity of services sector in Malaysia. Using employment multipliers, Beard et al. (2014) investigated the relationship between capital investment and employment in the information sector. In recent past, I-O framework has often been used in modeling the employment effects of new climate protection/energy strategies: Laitner et al. (1998) examined the effects of innovation-led climate strategy on employment. Using I-O tables, Neuwahl et al. (2008) analyzed the employment consequences of policies aimed to support biofuels in the European Union. Providing a case from Germany, Wydra (2011) investigated the production and employment impacts of biotechnology. Creating an index for employment quantification, Simas and Pacca (2014) assessed the employment generation potential of renewable energy technologies in Brazil. I-O modeling also provides a useful framework to explore the effects of foreign trade on employment: Reynolds (1987) used Chinese foreign trade statistics, and a World Bank I-O table for China, to explore the impact of economic reform on employment, trade, and income inequality. Chen et al. (2012) used I-O framework to estimate how exports affected the country's total domestic value added and employment structure in China. Kucera et al. (2012) investigated the effects of trade contraction on employment in India and South Africa, using social accounting matrices in a Leontief multiplier model. However, none of these studies examined employment interactions in the regional context.

Research on regional employment with the I-O model is very limited. Kolk (1983) introduced a methodology for incorporating price-induced technological substitution into a 
regional I-O forecasting model. The model was used to determine the employment impacts of rapidly escalating energy costs on a particular region in California. Heen and Flaaten (2007) developed a multiregional I-O model to investigate the spatial distribution of employment impacts of different fisheries management regimes and policies. Yet, the scope of these studies were restricted to either a particular industry or a specific region. To the authors' knowledge, there has been no attempt in the I-O literature to draw a complete picture of the regional employment interactions in an economy. Moreover, there has been no attempt to decompose the sectoral labor demand by regions in Turkey.

The aim of this study is to investigate the inter-sectoral sensitivities of the regional labor markets in Turkey in response to sectoral changes in the final demand. To do this, we will decompose the labor demand by sectors and regions. We adopt the methodology in GünlükŞenesen and Şenesen (2011) which decomposes the effects of final demand changes on employment for different labor categories (gender, skill etc.). We calculate each sector's own employment generation effects and regional employment multipliers with the most recent I-O tables published by Turkish Statistical Institute (TURKSTAT 2014a, 2014b).

The remainder of the paper is organized as follows. Section 1 describes the methodology we use in regional decomposition analysis. In Section 2, the data structure is discussed. Findings will be given in Section 3. In the last section, the concluding remarks will be discussed.

\section{Methodology}

I-O analysis is an important quantitative methodology that shows the interdependencies between the branches of a national economy and even between the branches of different, possibly competing economies (Ten Raa 2010: 13). Showing how dependent each sector is on every other sector, both as a purchaser of outputs and as a supplier of inputs, I-O accounts have been constructed for economies ever since Leontief's pioneering work (Leontief 1936; Lenzen 2007).

I-O models are usually based on a square matrix in which each row shows the allocation of an industry's total output among various production sectors and final demand. On the other hand, the columns of the matrix show the input (intermediate and primary) structure for each sector. In the I-O model, sectoral output vector $(x)$ in an economy can be written as

$$
x=A_{d} x+y,
$$

where $A_{d}$ represents direct domestic input coefficients matrix and $y$ represents the domestic final demand vector. $A_{d}$ is an $(n \times n)$ domestic input coefficient matrix containing the ratios of the amount of each input directly required from the row sector to produce one unit of a commodity in the column sector, and $y$ is an $(n \times 1)$ vector representing the final domestic demand for each sector (Oshita 2012). $n$ represents the number of sectors. Solving Eq. 1 for $(x)$, the following equilibrium equation is obtained:

$$
x=\left(I-A_{d}\right)^{-1} y=R y,
$$

$\left(I-A_{d}\right)^{-1}$ matrix is called the Leontief inverse matrix $(R)$. The elements of the Leontief matrix, $r_{j k}$ denote the demand for sector $k$ input to produce one unit of commodity in sector $j$. In other words, Eq. (2) represents the direct and indirect domestic production of each sector 
induced by final demand. The Leontief inverse matrix associates sectoral outputs with final demands (Miller, Blair 2009).

In order to obtain the regional labor requirements corresponding to the changes in the final demand, the following approach can be used (Gu, Rennison 2005; Günlük-Şenesen, Şenesen 2011):

$$
L x=L R y=E y .
$$

In the above equation, a typical element of $L, l_{c j}$ represents the labor requirements (in persons or hours) for region $c$ per unit output of sector $j(c=1, \ldots, 12 ; j=1, \ldots, n)$, and a typical element of $R, r_{j k}$ represents the (direct and indirect) output expansion in sector $j$ induced by final demand $k(j, k=1, \ldots, n)$. An element of $\mathrm{E}, e_{c k}$ shows the labor demand in region $c$ induced by final demand sector $k$. $\sum_{c} e_{c k}$ gives the overall labor requirement in the economy induced by a unitary increase in the final demand of sector $k$. When the methodology suggested by Günlük-Şenesen and Şenesen (2001) is adapted to the employment context, using a diagonal matrix, $\widehat{R^{*} k}$, the elements of which consist of the elements in the $k^{\text {th }}$ column of Leontief inverse matrix ), regional decomposition of the labor requirements can be obtained as follows:

$$
G^{k}=L \widehat{R^{* k}}
$$

An element of $G^{k}$ matrix, $g_{c j}^{k}$, represents the direct and indirect labor requirement by the $j^{\text {th }}$ sector in region $c$, induced by a unitary change in the final demand of the $k^{\text {th }}$ sector. While the row sums of $G^{k}$ give $e_{c k}$, the backward labor linkages of $k$ in region $c$, the column sums of $G^{k}$ give backward labor linkages of $k$ in sector $j$ :

$$
\begin{gathered}
\sum_{j} g_{c j}^{k}=e_{c k} ; \\
\sum_{c} g_{c j}^{k}=\left(\widehat{i^{\prime} L}\right) R .
\end{gathered}
$$

In Eq. $6, i^{\prime}$ represents the row vector of unity for summation. Under the assumption of homogeneous labor, $\left(\widehat{i^{\prime} L}\right)$ stands for the diagonal matrix of total labor coefficients. Therefore, backward linkage of sector $k$ in the economy can be obtained as follows (Günlük-Şenesen, Şenesen 2011):

$$
\sum_{c} \sum_{j} g_{c j}^{k}=i^{\prime}\left(\widehat{i^{\prime} L}\right) R=\sum_{c} e_{c k} .
$$

Incorporating the total flow concept developed by Szyrmer (1992), we can obtain the output multiplier as follows:

$$
\frac{\partial x_{j}}{\partial x_{k}}=\frac{\partial x_{j} / \partial y_{k}}{\partial x_{k} / \partial y_{k}}=\frac{r_{j k}}{r_{k k}} .
$$

This multiplier takes the value of 1 for $j=k$. Hence, the labor demand by the $j^{\text {th }}$ sector in the $c^{\text {th }}$ region, related to the changes in the output of the $k^{\text {th }}$ sector is given by

$$
l_{c j} \frac{r_{j k}}{r_{k k}}
$$


If we substitute the above definition in Equation 4, we obtain the following equation which can transform the effects of final demand changes on employment into the impact of output changes on labor demand:

$$
H^{k}=\widehat{L R^{* k}}\left(\widehat{r_{k k}^{-1}}\right)=G^{k}\left(\widehat{r_{k k}^{-1}}\right) \text {. }
$$

$H^{k}$ gives the labor requirements by the $j^{\text {th }}$ sector in the $c^{\text {th }}$ region, in association with the output of sector $k$. The details of the relationship between the matrices $H^{k}$ and $G^{k}$ can be found in Günlük-Şenesen and Şenesen (2011).

\section{Data and observations}

In this study, three different datasets are used: (a) I-O tables for the year 2002 (the most recent I-O tables published by TURKSTAT), (b) the Household Labor Force Survey (HLFS) for 2002 and (c) the HLFS for 2005.

Nine main sectors are examined for 12 regions. Sectoral employment data by regions is not available in the 2002 HLFS. In order to generate regional employment figures for 2002, we used the ratios from 2005 HLFS. We assumed that the sectoral and the regional employment structure did not change between 2002 and 2005. Comparison of 2002 HLFS results with that of 2005 supports the view that this assumption is valid. Sectoral employment rate differences between 2002 and 2005 figures are lower than 1\% in all sectors but agriculture (1.92\%).

International Standard Industrial Classification of All Economic Activities (ISIC) is a structure suggested by United Nations Statistics Division. Although TURKSTAT I-O tables for the year 2002 provide data based on ISIC Rev. 3 (59 sectors) classification, regional employment statistics provided by HLFS is based on ISIC Rev. 2 (9 sectors) classification. Due to this limitation, we have aggregated 59 sectors I-O tables into 9 main sectors. These sectors are: Agriculture, forestry, hunting and fishing (AGR); mining and quarrying (MIN); manufacturing (MAN); electricity, gas and water (ELE); construction (CON); wholesale and retail trade, hotels and restaurants (TRD); transportation, communication and storage (TRN); finance, insurance, real estate and business services (FIN); community, social and personal services (SOC).

Region classification used in this study is based on the Nomenclature of Territorial Units for Statistics (NUTS) Level 1 criteria. Since NUTS classification is used only by European Union member states, version used in Turkey, as a candidate country, is named statistical regions (SR-IBBS). Regions classified with respect to Level 1 are: Istanbul (IST), Western Marmara (WMA), Aegean (AEG), Eastern Marmara (EMA), Western Anatolia (WAN), Mediterranean (MED), Middle Anatolia (MAN), Western Black Sea (WBS), Eastern Black Sea (EBS), North Eastern Anatolia (NEAN), Middle Eastern Anatolia (MEAN), and South Eastern Anatolia (SEAN) (see Fig. 1).

Studies which investigate industrial development, health and education levels in Turkey show that the priorities of the east and the west significantly differ (Özaslan et al. 2006; Celebioglu, Dall'erba 2010). Various policy instruments such as integrated regional development 


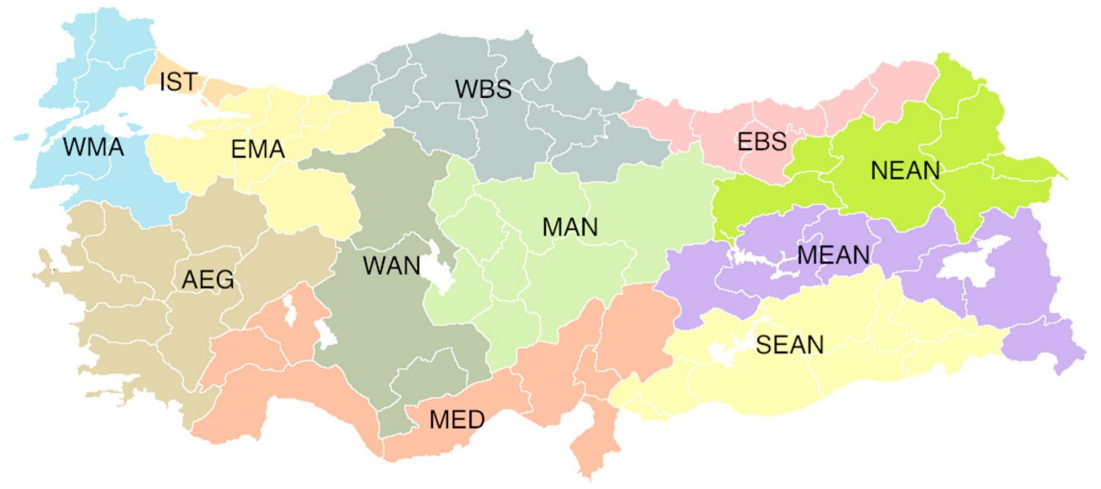

Fig. 1. Regions of Turkey (Level 1)

plans, investment incentives, priority development areas policies, organized industrial zones, small industry sites and rural development projects have been introduced to speed up regional development and to eliminate the imbalances between regions. In addition to public investment policies, state aids provided and personnel policies implemented to attract the private sector to these regions have been major public tools used to eliminate the imbalance between these regions (Özaslan et al. 2006).

A comparison of the regions in Turkey reveals that IST, WAN, EMA, AEG, and WMA are the most developed ones in terms of health, education and industrialization. The position of Marmara region (consists of IST, EMA, and WMA) is mainly determined by Istanbul, the most populated city of Turkey. Industrial and commercial dynamism have in the past spread from Istanbul to the entire region and made the Marmara Region the country's most dynamic center of development and attraction. Ankara, the capital of Turkey, is the business center of WAN. Izmir is the commercial and economic center of the AEG region. The development process in AEG is diverse and spatially balanced. Organized industrial zones were implemented in the AEG region. This group is followed by MED, WBS, MAN, and EBS regions. In the past, these regions benefitted from various rural development projects. SEAN, MEAN and NEAN regions have the lowest levels of health, education and industrialization levels. Besides, there is a significant outward migration in these regions. The need for policies that will stop migration can be considered among the priorities of these regions. A general evaluation of the regional development in Turkey would show that there is an imbalance between the priorities of the regions in terms of income, demographic structure, physical and social infrastructure, entrepreneurship, human resources, education level, access to health services, environmental quality, employment and the role of women (Özaslan et al. 2006).

To provide insight into the relative importance of employment for region, we use employment to population ratio (EPR) indicator. EPR represents the share of employment in working age population. Average EPR for Turkey was $41 \%$ in 2005 . Figure 2 shows that EPR figures are below 50\% level in all regions except EBS. Lowest EPR's are observed in MEAN and SEAN regions. 


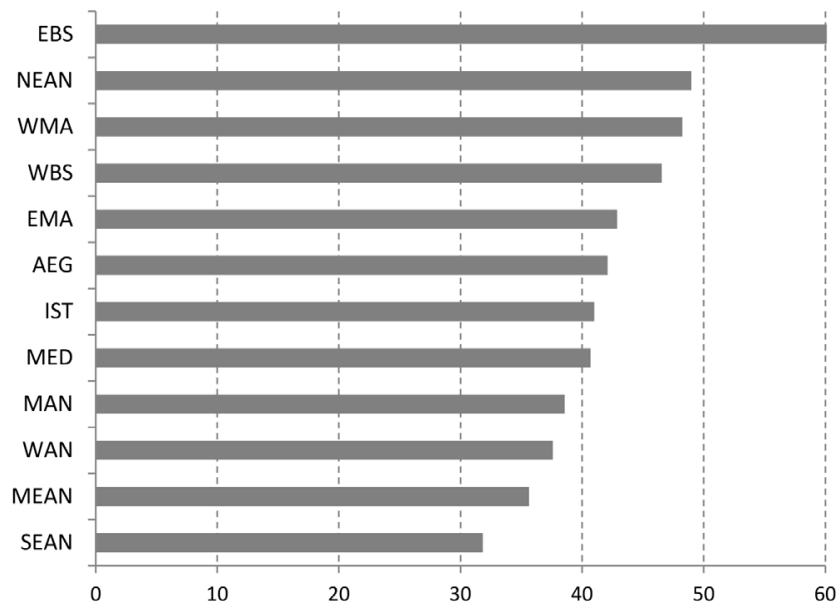

Fig. 2. Share of employment in population, 2005 (15+) (EPR) Source: TURKSTAT (2014a).

Table 1. Intra-regional employment shares of sectors

\begin{tabular}{lcccccccccc}
\hline & AGR & MIN & MAN & ELE & CON & TRD & TRN & FIN & SOC & TOTAL \\
\hline SEAN & 0.345 & 0.006 & 0.116 & 0.005 & 0.063 & 0.198 & 0.073 & 0.019 & 0.173 & 1.00 \\
MEAN & 0.544 & 0.002 & 0.063 & 0.003 & 0.038 & 0.120 & 0.042 & 0.019 & 0.169 & 1.00 \\
NEAN & 0.624 & 0.001 & 0.029 & 0.006 & 0.018 & 0.117 & 0.035 & 0.013 & 0.158 & 1.00 \\
EBS & 0.638 & 0.001 & 0.046 & 0.004 & 0.029 & 0.116 & 0.029 & 0.017 & 0.119 & 1.00 \\
WBS & 0.498 & 0.014 & 0.102 & 0.004 & 0.034 & 0.158 & 0.033 & 0.020 & 0.137 & 1.00 \\
MAN & 0.410 & 0.002 & 0.136 & 0.004 & 0.046 & 0.166 & 0.036 & 0.023 & 0.176 & 1.00 \\
MED & 0.340 & 0.002 & 0.135 & 0.004 & 0.052 & 0.221 & 0.049 & 0.033 & 0.164 & 1.00 \\
WAN & 0.203 & 0.004 & 0.154 & 0.005 & 0.055 & 0.220 & 0.057 & 0.057 & 0.245 & 1.00 \\
EMA & 0.220 & 0.002 & 0.315 & 0.004 & 0.048 & 0.198 & 0.048 & 0.032 & 0.134 & 1.00 \\
AEG & 0.336 & 0.014 & 0.194 & 0.006 & 0.045 & 0.194 & 0.040 & 0.032 & 0.140 & 1.00 \\
WMA & 0.418 & 0.004 & 0.161 & 0.006 & 0.034 & 0.178 & 0.032 & 0.025 & 0.142 & 1.00 \\
IST & 0.022 & 0.001 & 0.381 & 0.006 & 0.057 & 0.244 & 0.075 & 0.071 & 0.143 & 1.00 \\
\hline
\end{tabular}

Table 1 shows the intra-regional employment shares of sectors. Agriculture, trade, manufacturing and social services sectors are the most essential sectors at all regions. Manufacturing in IST and EMA, social services in WMA and agriculture in other nine regions have the highest share in intra-regional employment. Share of agriculture is more than 50\% in EBS, NEAN and MEAN regions. Shares of Mining and Electricity sectors in total employment are the lowest ones in all regions and are around 1\% levels.

Figure 3 shows the value added per worker (VAW) in billion TL by sectors. AGR and SOC are the sectors with the lowest levels of VAW followed by TRD sector. There are more than three million agriculture enterprises in Turkey and $83 \%$ of them are smaller than 10 hectares 


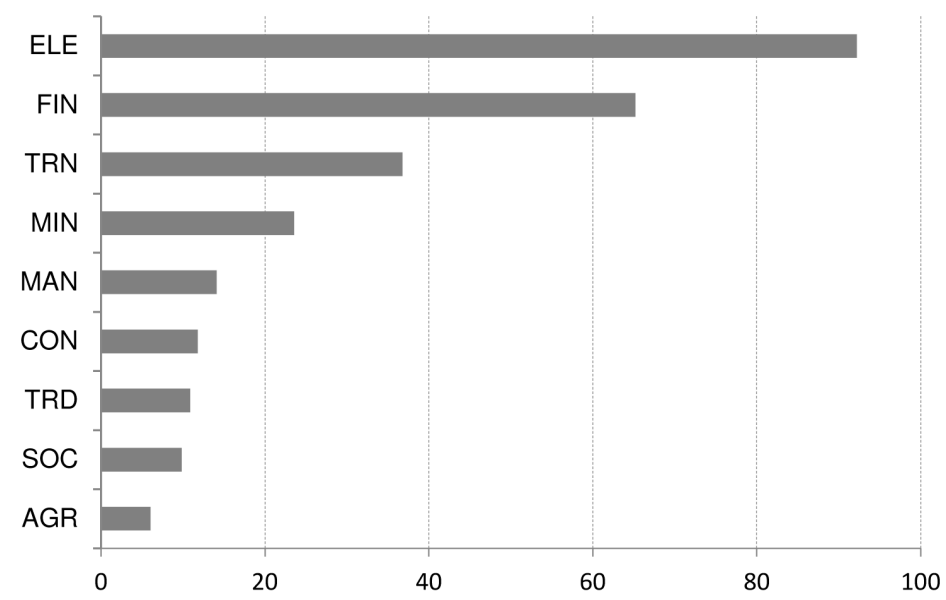

Fig. 3. Value added per worker, 2002 (billion TL) Source: TURKSTAT (2014a, 2014b).

(Gülçubuk, Aluftekin 2006). According to 2005 HLFS, around one fourth of the employed people were working in AGR. However, the contribution of the sector to GDP was around $10 \%$ level. Figure 3 also shows that labor productivity for CON and MAN sectors are at low to mediocre levels. On the other hand, the sector with the highest VAW is ELE followed by FIN and TRN sectors. As ELE consists of Electricity, Gas, and Water subsectors the productivity levels of which are very high, VAW figures significantly differ from that of other sectors.

\section{Findings}

Direct labor coefficient matrix is an indicator of regional concentration of employment with regard to sectors. Direct labor coefficients might be useful in providing insight on the sectoral labor productivities. A typical element of the matrix shows the number of workers per unit (one billion TL in 2002 prices) output of the sector under investigation. In other words, the reciprocals of the labor coefficients stand for the sectoral labor productivities.

Figure 4 shows the direct labor coefficients of the sectors by the geographic regions of Turkey. Agriculture sector has the highest labor coefficient values in all regions except IST and WAN. In IST region, trade has the highest coefficient. Social services sector, followed by agriculture, employs greatest number of workers per unit output in WAN. In fact, social services sector has the second highest labor coefficients in 9 out of 12 regions. Similarly, trade is remarkable for relatively large number of employees per unit output. In AEG and WBS regions, mining sector has the second highest direct labor coefficient. Together with Table 1, Figure 4 draws our attention to low level of labor productivity in agriculture. This may be partly due to relatively high number of people employed in this sector. However, it should be noted that in regions like WAN and EMA (in which agriculture does not have the largest share in the labor market) the labor coefficients of agriculture sector are still among the highest. 


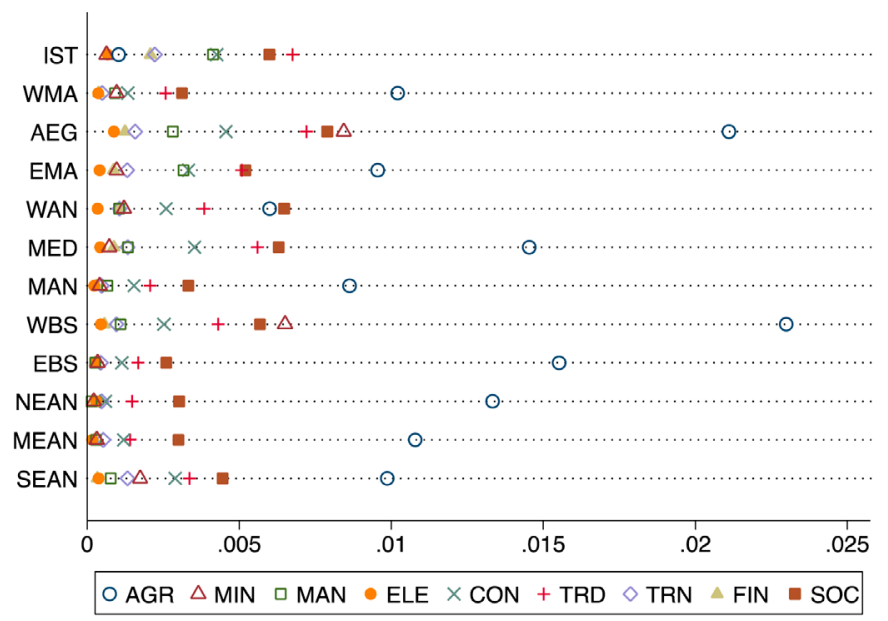

Fig. 4. Direct labor coefficients

Effects of a unit change in the final demand of each sector on the employment levels of nine sectors are calculated for 12 regions by using $G$ matrix given in Equation 4 and the same effects of the output of each sector are found by using $H$ matrix given in Eq. 10.

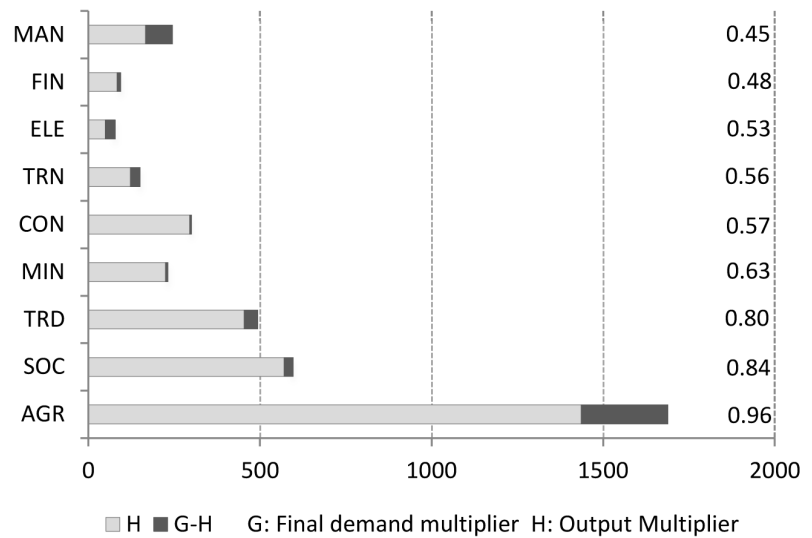

Fig. 5. Own effects for employment (10000 x multiplier) and closeness

Figure 5 shows the own employment effects of each sector in response to a change in the final demand. Right-aligned numbers represent shares of own effects in total (closeness). The sectors with lower closeness figures have stronger employment linkages. Manufacturing and finance have the strongest linkages. Agriculture, social services and trade are the most isolated sectors. Employment generation capacity of a change in the final demand is the highest in agriculture sector. On the other hand, the least sensitive sectors are electricity, finance and transportation.

Employment generation/association potentials of nine sectors are summarized in Figure 6. It should be noted that, in an expansionary economic environment, $G$ multiplier represents "employment generation of final demand increase" and $H$ multiplier stands for "employment associated with output". Yet, in a recessive climate $G$ and $H$ multipliers would denote "employment contraction due to final demand squeeze" and "employment contraction associated with output” (Günlük-Şenesen, Şenesen 2011: 242). 


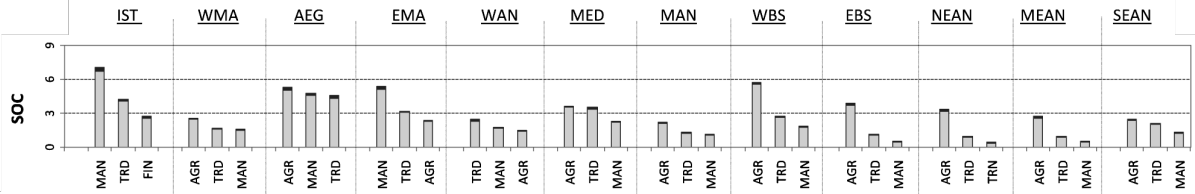

z

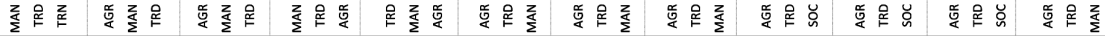

z

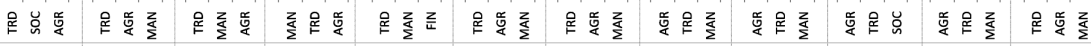

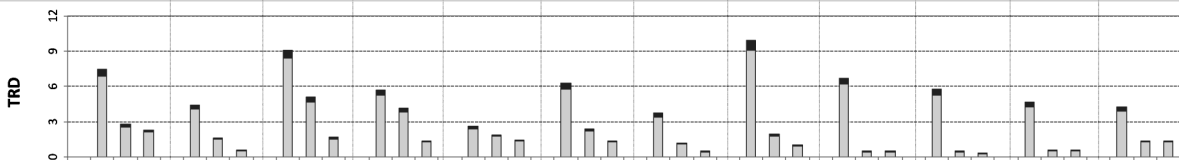

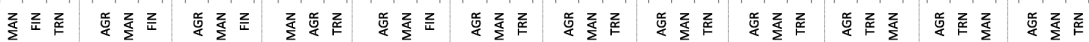

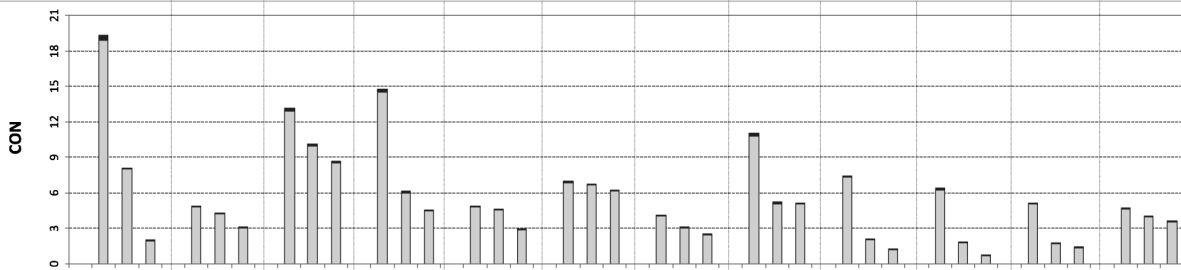

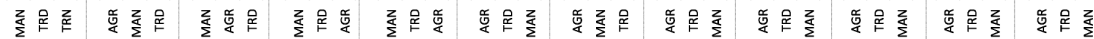

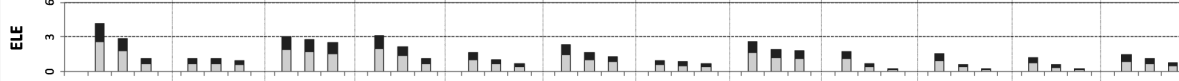

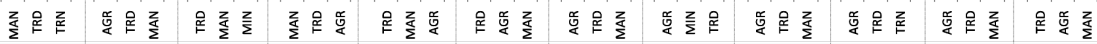
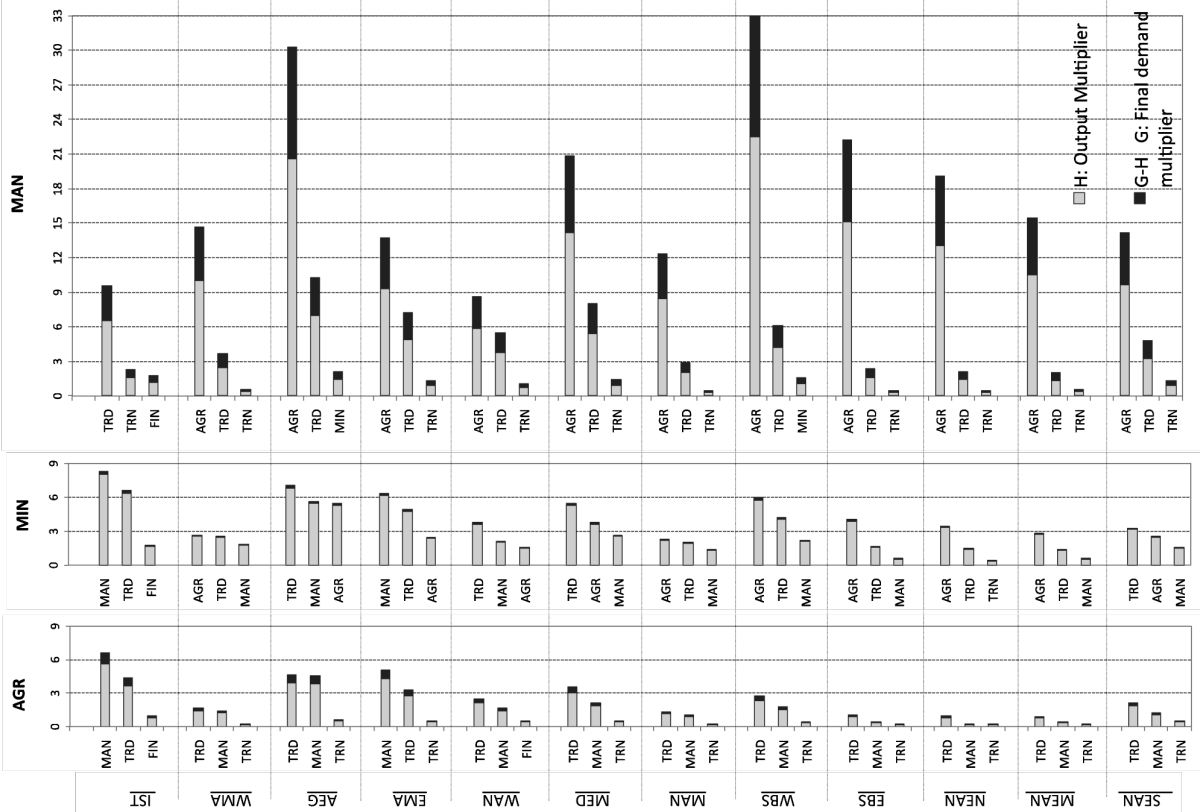
Employment generation/association effects of agriculture are mostly observed in manufacturing, trade and transportation sectors. These effects are significant in IST and AEG, while weaker in NEAN and MEAN. The influence of mining is strongly observed in IST and AEG regions, while the linkage is weak in MAN and MEAN. Agriculture, trade and manufacturing are the most sensitive sectors to mining.

Manufacturing creates the biggest inter-industrial employment effect. The strong influence of manufacturing on agriculture sector is notable. A change in the final demand of manufacturing sector is mostly influential on agriculture in all regions but Istanbul. A regional perspective reveals that inter-industrial linkages of manufacturing sector are stronger in AEG and WBS, and weaker in IST, WAN and MAN. A closer look at Fig. 6 shows that, in a recessive economic climate, employment contraction due to final demand squeeze in manufacturing sector will be most significant in agriculture sector in AEG and WBS regions. A possible contraction in manufacturing sector will also be influential on trade sector, particularly in IST and AEG regions.

Employment generation potential of construction sector is less than that of manufacturing. Construction has strong employment influence on manufacturing in the west and on agriculture in the middle and east of Turkey. Hence, impact of a final demand squeeze in the construction sector will be heterogeneous among regions. Immediate effects of such a recession period will be apparent on the manufacturing sector in IST, EMA, and AEG regions.

Inter-industrial employment generation effects of electricity, trade, transportation, finance and social services have similar features. First of all, these sectors have quite weak employment influences. The most sensitive sector to this group is manufacturing sector in the west (excluding WMA) and agriculture sector in the middle and eastern parts of Turkey. IST, AEG and WBA are the most sensitive regions to this group of sectors.

A closer look at electricity reveals that the strongest employment effects of the sector are on manufacturing in IST and EMA regions and trade in AEG. Figure 6 also shows that, influence of trade on agriculture is notable in all regions except IST. In fact, trade sector does not have any significant impact on non-agricultural employment in the east.

A change in the final demand of transportation is influential on trade sector in all regions. Figure 6 also indicates that finance and social services sectors have relatively strong employment generation effect on manufacturing sector in IST and EMA regions.

The difference between $G$ and $H$ values of a sector is proportional to $r_{k k}$ (see Eq. 10) and shows the employment sensitivity of a sector to changes in its own final demand. Hence, in response to final demand squeezes, manufacturing and electricity are the most vulnerable sectors; on the other hand, construction, mining and social services are the most robust ones.

The most influential sectors in the regions with low EPR are also determined. Trade, social services and manufacturing are the sectors with highest impact in IST. Besides, agriculture, social services, trade and construction are the most effective sectors for WAN, MAN, MEAN and SEAN. 


\section{Conclusions}

In this study, we elaborated the inter-sectoral sensitivities of regional labor markets in Turkey in response to changes in the final demand of each sector. We decomposed the labor demand by sectors and regions using an I-O based methodology. Our results show that the sectors with high employment generation potentials are agriculture, social services, and trade. On the other hand, electricity and finance are the sectors with the lowest employment generation potentials. We have also computed the influence of a specific sector on the employment levels of other sectors by regions and found that the most influential sectors are manufacturing and construction, while the sectors with the least significant influences are agriculture and electricity.

A key implication of the study is that policy makers should consider inter-sectoral and inter-regional employment generation potentials. Our study indicates very strong mutual employment generation effects between manufacturing and agriculture. This relation might be interpreted as a reflection of agriculture based industrialization in Turkey. Accordingly, the most significant employment effects of an expansionary policy in manufacturing will be observed in agriculture, particularly in WBS, AEG, EBS and MED regions. Similarly, manufacturing sector is sensitive to final demand changes in agriculture, especially in IST and EMA regions. It should also be noted that employment outcomes of government incentives on manufacturing sector would be observed in trade in IST.

Our results show that an overall support policy on construction will also have significant employment effects in manufacturing sector in IST and EMA. Such a policy will have notable employment effects in agriculture sector in WBS and EBS. Furthermore, a recessive period in the finance sector would result in notable employment contraction in manufacturing sector in IST and EMA regions and in agriculture sector in AEG and WBS regions. Consequently, when suggesting policies for a particular sector, not only the effects on the employer sector (own effects) but also the regional employment generation effects should be taken into account.

A notable characteristic of agriculture sector is disguised unemployment. Agriculture is the sector with the lowest level of VAW among all. Since agricultural dependence is one of most crucial problems of the eastern part of Turkey, suggesting policy implications for the regions with low EPR is a critical issue. Hence, in order to overcome regional disparities and promote practices that will stop migration, policy designers should better focus on non-agricultural employment. Our study reveals that social services, manufacturing, and construction are the key sectors to decrease the non-agricultural unemployment.

In the future studies, the methodology could be applied using different labor categories like education levels, age groups, or ethnicities. Moreover, with some modifications, the model could be improved in order to incorporate two labor category dimensions, such as region and gender, simultaneously.

\section{References}

Abe, Y. 2013. Regional variations in labor force behavior of women in Japan, Japan and the World Economy 28: 112-124. http://dx.doi.org/10.1016/j.japwor.2013.08.004

Baltagi, B. H.; Baskaya, Y. S.; Hulagü, T. 2013. How different are the wage curves for formal and informal workers? Evidence from Turkey, Papers in Regional Science 92(2): 271-283. 
Beard, T. R.; Ford, G. S.; Kim, H. 2014. Capital investment and employment in the information sector, Telecommunications Policy 38(4): 371-382. http://dx.doi.org/10.1016/j.telpol.2013.12.001

Celebioglu, F.; Dallerba, S. 2010. Spatial disparities across the regions of Turkey: an exploratory spatial data analysis, The Annals of Regional Science 45: 379-400. http://dx.doi.org/10.1007/s00168-009-0313-8

Chen, X.; Cheng, L. K.; Fung, K. C.; Lau, L. J.; Sung, Y.-W.; Zhu, K.; Yang, C.; Pei, J.; Duan, Y. 2012. Domestic value added and employment generated by Chinese exports: a quantitative estimation, China Economic Review 23(4): 850-864. http://dx.doi.org/10.1016/j.chieco.2012.04.003

Constantini, M.; Lupi, C. 2006. Divergence and long-run equilibria in Italian regional unemployment, Applied Economics Letters 13: 899-904. http://dx.doi.org/10.1080/13504850500425758

Edler, G.; Ribakova, T. 1994. The impact of industrial robots on the level and structure of employment in Germany - a simulation study for the period 1980-2000, Technological Forecasting and Social Change 45(3): 255-274. http://dx.doi.org/10.1016/0040-1625(94)90049-3

Elveren, A. Y. 2010. Wage inequality in Turkey: decomposition by statistical regions: 1980-2001, Review of Urban \& Regional Development Studies 22(1): 55-72. http://dx.doi.org/10.1111/j.1467-940X.2010.00169.x

Filiztekin, A. 2009. Regional unemployment in Turkey, Papers in Regional Science 88: 863-878. http://dx.doi.org/10.1111/j.1435-5957.2009.00237.x

Gezici, F.; Hewings, G. J. D. 2007. Spatial analysis of regional inequalities in Turkey, European Planning Studies 15(3): 383-403. http://dx.doi.org/10.1080/09654310601017091

Gezici, F.; Hewings, G. J. D. 2004. Regional convergence and the economic performance of peripheral areas in Turkey, Review of Urban \& Regional Development Studies 16(2): 113-132. http://dx.doi.org/10.1111/j.1467-940X.2004.00082.x

$\mathrm{Gu}, \mathrm{W}$;; Rennison, L. W. 2005. The effect of trade on productivity growth and the demand for skilled workers in Canada, Economic Systems Research 17: 279-296. http://dx.doi.org/10.1080/09535310500221815

Gülçubuk, B.; Aluftekin, N. 2006. Impact of international agricultural policies on rural poverty in Turkey, International Business \& Economics Research Journal 5(1): 9-18.

Günçavdı, Ö.; Küçükçifçi, S.; Mckay, A. 2003. Adjustment, stabilisation and the analysis of the employment structure in Turkey: an input-output approach, Economics of Planning 36: 315-331. http://dx.doi.org/10.1023/B:ECOP.0000038300.31498.7f

Günlük-Şenesen, G.; Şenesen, Ü. 2001. Reconsidering import dependency in Turkey: the break-down of sectoral demands with respect to suppliers, Economic Systems Research 13: 417-428. http://dx.doi.org/10.1080/09535310120089798

Günlük-Şenesen, G.; Şenesen, Ü. 2011. Decomposition of labour demand by employer sectors and gender: findings for major exporting sectors in Turkey, Economic Systems Research 23: 233-253. http://dx.doi.org/10.1080/09535314.2011.582031

Heen, K.; Flaaten, O. 2007. Spatial employment impacts of fisheries management: a study of the Barents Sea and the Norwegian Sea fisheries, Fisheries Research 85: 74-83. http://dx.doi.org/10.1016/j.fishres.2006.12.004

Jonasson, E. 2011. Informal employment and the role of regional governance, Review of Development Economics 15(3): 429-441. http://dx.doi.org/10.1111/j.1467-9361.2011.00618.x

Kanbur, R.; Zhang, X. 1999. Which regional inequality? The evolution of rural-urban and inland-coastal inequality in China from 1983 to 1995, Journal of Comparative Economics 27(4): 686-701. http://dx.doi.org/10.1006/jcec.1999.1612

Karahasan, B. C.; Lopez-Baso, E. 2013. The spatial distribution of human capital: can it really be explained by regional differences in market access?, International Regional Science Review 36(4): 451-480. http://dx.doi.org/10.1177/0160017613491492 
Kolk, D. X. 1983. Regional employment impact of rapidly escalating energy costs, Energy Economics 5: 105-113. http://dx.doi.org/10.1016/0140-9883(83)90017-8

Koster, S. 2011. Individual foundings and organizational foundings: their effect on employment growth in The Netherlands, Small Business Economics 36: 485-501. http://dx.doi.org/10.1007/s11187-009-9253-z

Kucera, D.; Leanne, R.; Uexhull, E. 2012. Trade contraction and employment in India and South Africa during the Global Crisis, World Development 40(6): 1122-1134.

http://dx.doi.org/10.1016/j.worlddev.2011.11.003

Laitner, S.; Bernow, S.; DeCicco, J. 1998. Employment and other macroeconomic benefits of an innovation-led climate strategy for the United States, Energy Policy 26(5): 425-432.

http://dx.doi.org/10.1016/S0301-4215(97)00160-2

Lenzen, M. 2007. Structural path analysis of ecosystem networks, Ecological Modelling 200: 334-342. http://dx.doi.org/10.1016/j.ecolmodel.2006.07.041

Leontief, W. W. 1936. Quantitative input and output relations in the economic systems of the United States, The Review of Economics and Statistics 18: 105-125. http://dx.doi.org/10.2307/1927837

LeSage, J. P.; Magura, M. 1991. Using inter-industry input-output relations as a Bayesian prior in employment forecasting models, International Journal of Forecasting 7(2): 231-238.

http://dx.doi.org/10.1016/0169-2070(91)90056-2

Li, H.; Cheng, S. E.; Haynes, K. E. 2011. The employment effects of new business formation: a regional perspective, Economic Development Quarterly 25: 282-292. http://dx.doi.org/10.1177/0891242411407310

Miller, R. E.; Blair, P. D. 2009. Input-output analysis: foundations and extensions. $2^{\text {nd }}$ ed. Cambridge: Cambridge University Press. http://dx.doi.org/10.1017/CBO9780511626982

Neuwahl, F.; Löschel, A.; Mongelli, I.; Delgado, L. 2008. Employment impacts of EU biofuels policy: combining bottom-up technology information and sectoral market simulations in an input-output framework, Ecological Economics 68(1-2): 447-460. http://dx.doi.org/10.1016/j.ecolecon.2008.04.018

Niebuhr, A.; Granato, N.; Haas, A.; Hamaan, S. 2012. Does labour mobility reduce disparities between regional labour markets in Germany?, Regional Studies 46(7): 841-858.

http://dx.doi.org/10.1080/00343404.2010.532118

Onaran, O. 2009. Wage share, globalization and crisis: the case of the manufacturing industry in Korea, Mexico and Turkey, International Review of Applied Economics 23: 113-134. http://dx.doi.org/10.1080/02692170802700435

Oshita, Y. 2012. Identifying critical supply chain paths that drive changes in CO2 emissions, Energy Economics 34: 1041-1050. http://dx.doi.org/10.1016/j.eneco.2011.08.013

Özaslan, M.; Dinçer, B.; Özgür, H. 2006. Regional disparities and territorial indicators in Turkey: socioeconomic development index, ERSA Conference Papers, No ersa06p858.

Reynolds, B. L. 1987. Trade, employment, and inequality in postreform China, Journal of Comparative Economics 11(3): 479-489. http://dx.doi.org/10.1016/0147-5967(87)90068-0

Rodrik, D. 2012. The Turkish economy after the global financial crisis, Ekonomi-tek 1: 41-61.

Sauian, M. S.; Kamarudin, N.; Rani, R. M. 2013 Labor productivity of services sector in Malaysia: analysis using Input-Output approach, Procedia Economics and Finance 7: 35-41.

http://dx.doi.org/10.1016/S2212-5671(13)00215-3

Shankar, R.; Shah, A. 2003. Bridging the economic divide within countries: a scorecard on the performance of regional policies in reducing regional income disparities, World Development 31(8): 1421-1441. http://dx.doi.org/10.1016/S0305-750X(03)00098-6

Simas, M.; Pacca, S. 2014. Assessing employment in renewable energy technologies: a case study for wind power in Brazil, Renewable and Sustainable Energy Reviews 31: 83-90.

http://dx.doi.org/10.1016/j.rser.2013.11.046 
Szyrmer, J. M. 1992. Input-output coefficients and multipliers from a total-flow perspective, Environment and Planning A 24: 921-937. http://dx.doi.org/10.1068/a240921

Ten Raa, T. 2010. Input-Output economics: theory and applications - featuring asian economies. London: World Scientific.

Tunal, İ. 2003. Background study on labour market and employment in Turkey. Iskur, Ankara.

TURKSTAT. 2014a. Household Labor Force Statistics [online], [cited 18 March 2014]. Available from Internet: http://www.turkstat.gov.tr/PreTablo.do?alt_id=1007

TURKSTAT. 2014b. Input-Output Tables [online], [cited 18 March 2014]. Available from Internet: http:// www.turkstat.gov.tr/PreTablo.do?alt_id=1021

Wydra, S. 2011. Production and employment impacts of biotechnology-Input-Output analysis for Germany, Technological Forecasting and Social Change 78(7): 1200-1209.

http://dx.doi.org/10.1016/j.techfore.2011.03.002

Umut GÜNDÜZ is a research assistant at the department of Management Engineering in Istanbul Technical University and a phD candidate at the department of Economics in Marmara University. His main research interests are statistical decision making, economic modeling and policies on sustainable development.

Tolga KAYA is a full time researcher and lecturer at the department of Management Engineering in Istanbul Technical University. His research areas are consumer modeling, statistical decision making, input-output modeling, multicriteria decison making, and fuzzy applications in business and management. He has published several papers and presented his research at a number of international conferences in these areas. 